\title{
The pharmacological and clinical aspects behind dose loading of biological disease modifying anti-rheumatic drugs (bDMARDs) in auto-immune rheumatic diseases (AIRDs): rationale and systematic narrative review of clinical evidence
}

Gerlienke E. Geurts-Voerman ${ }^{1 *}$, Lise M. Verhoef ${ }^{1}$, Bart J. F. van den Bemt ${ }^{2,3}$ and Alfons A. den Broeder ${ }^{1,4}$

\begin{abstract}
Background: Dose loading of biological disease modifying anti-rheumatic drugs (bDMARDs) in auto-immune rheumatic diseases (AIRDs) is performed to achieve steady state drug concentrations earlier after treatment start compared to dosing regimens without loading. Although loading inherently results in increased costs, treatment targets in terms of reduced disease activity may be achieved at an earlier state. It is an interesting topic that, surprisingly, has not received much attention in literature.

Methods: In this review, we aimed at providing a theoretical description of the pharmacodynamic / -kinetic rationale for dose loading of bDMARDs in AIRDs and to systematically review the clinical evidence on the effectiveness of dose loading on disease activity in AIRDs.

Results: Only a small number of studies $(n=5)$ has been published comparing the effectiveness of dose loading versus a regimen without dose loading of bDMARDs in AIRDs, addressing abatacept $(n=2)$, certolizumab pegol $(n=1)$, and secukinumab $(n=2)$. These studies provide insufficient evidence on superiority of dose loading in terms of disease activity compared to a dosing regimen without loading, while safety issues might be comparable.

Conclusions: Although dose loading is commonly adopted for several bDMARDs in AIRDs, scientific evidence on its effectiveness and safety is surprisingly scarce and does not suggest superiority compared to a regimen without dose loading. More research in this field, also with regard to the pharmaco-economic consequences of dose loading, is urgently needed.
\end{abstract}

Keywords: Auto-immune rheumatic disease (AIRD), Biological DMARD, Dose loading, Pharmacodynamics / pharmacokinetics, Pharmaco-economics

\footnotetext{
*Correspondence: g.voerman@maartenskliniek.nl

'Department of Rheumatology, Sint Maartenskliniek, PO Box 9011, 6500, GM, Nijmegen, The Netherlands

Full list of author information is available at the end of the article
}

(c) The Author(s). 2020 Open Access This article is licensed under a Creative Commons Attribution 4.0 International License, which permits use, sharing, adaptation, distribution and reproduction in any medium or format, as long as you give appropriate credit to the original author(s) and the source, provide a link to the Creative Commons licence, and indicate if changes were made. The images or other third party material in this article are included in the article's Creative Commons licence, unless indicated otherwise in a credit line to the material. If material is not included in the article's Creative Commons licence and your intended use is not permitted by statutory regulation or exceeds the permitted use, you will need to obtain permission directly from the copyright holder. To view a copy of this licence, visit http://creativecommons.org/licenses/by/4.0/ The Creative Commons Public Domain Dedication waiver (http://creativecommons.org/publicdomain/zero/1.0/) applies to the data made available in this article, unless otherwise stated in a credit line to the data. 


\section{Background}

The introduction of biological disease-modifying antirheumatic drugs (bDMARDs) about two decades ago, resulted in significantly improved treatment outcomes and quality of life in patients with auto-immune rheumatic diseases (AIRDs), the most prevalent being rheumatoid arthritis (RA), psoriatic arthritis (PsA), and axial spondyloarthropathies (SpA). Tumor Necrosis Factor alpha inhibitors (TNFi's) were the first to enter the market, and were followed by other targeted drugs such as IL-1 receptor antagonists, anti-IL-6R antibodies, IL-17 inhibitors, CTLA4 inhibitors, and anti CD20 antibodies (see Table 1). Efficacy and safety profiles have systematically been investigated. Safety data generally seem favourable and the drugs are well tolerated, although side effects such as a small increased risk of infection, tuberculosis reactivation and biological-specific adverse events are reported [1]. Another major 'side effect' of biologicals are their associated costs. For example, treatment with TNF alpha inhibitors in the Netherlands roughly ranges from $€ 13.000$ to $€ 18.000$ (www.medicijnkosten.nl), with even higher costs in the USA $(\$ 27.000-\$ 32.000)$ for a year of therapy [2].

Some biologicals, such as abatacept and infliximab, are administered using dose loading (i.e. higher dosing during treatment start) according to the Summary of Product Characteristics (SmPC), while others, such as etanercept and adalimumab, are applied without. The choice whether or not to advise a loading dose seems to be independent of the half-life of the bDMARD. Also, within a specific drug the use of dose loading often varies between indication, and dose loading is more often proposed, for example, for inflammatory bowel disease and psoriasis than for AIRDs (see Table 1). The use and rationale of dose loading of bDMARDs when starting treatment is therefore an interesting topic that, surprisingly, has not received much attention in literature, except for several pharmacokinetic modelling studies. The modelling studies provide us data on the potential effects of loading, but how this is translated to clinical outcome remains hypothetical.

The assumed rationale for dose loading is the achievement of steady state serum drug concentrations (Css) earlier after treatment start, hypothetically resulting in the achievement of treatment targets at an earlier stage. Dose loading is generally used when it is necessary to achieve effective concentrations as soon as possible, for example in the treatment of infections or cardiac arrhythmias. In AIRD, one could debate whether this is clinically relevant, especially since it may induce more (serious) side effects, and also induces higher medication costs.

In this narrative review, we will elucidate the rationale for dose loading of bDMARDs from a pharmacokinetic / -dynamic perspective, and we present a systematic review addressing the clinical evidence on the efficacy of dose loading on disease activity in patients with AIRDs.

\section{The rationale of dose loading of bDMARDs in AIRDs from a pharmacokinetic / -dynamic perspective \\ The goal of dose loading}

The main goal of dose loading is to reach an effective target steady state concentration (Css) at an earlier state, resulting in a faster clinical response. In pharmacokinetics, the Css refers to the situation where the overall intake of a drug is fairly in dynamic equilibrium with its elimination. In practice, it is generally considered that Css is reached after 4-5 times the half-life for a drug $\left(\mathrm{T}_{1 / 2}\right)$. In some medical conditions, the time to attain Css after multiple doses of a drug is too long relative to the temporal demands of the condition being treated. Lidocain for example, which can be used to treat cardiac arrhythmias, has a $T_{1 / 2}$ of $1-2 \mathrm{~h}$. In this medical emergency, however, it is unacceptable to wait $4-10 \mathrm{~h}$ until Css is reached. In that case, it is therapeutically desirable to accelerate the time until the drug reaches the target concentration by giving a loading dose. By using a loading dose, the peak concentration is reached rapidly which is necessary to compete with clearance, so that the desired effect is achieved sooner [3]. Besides this pharmacokinetic rationale, other considerations for applying dose loading regimens are for instance when the medical condition results in high loss of the drug, such as in protein losing enteropathies in inflammatory bowel diseases, when the inflammatory load is high with subsequently high drug consumption in the first period, or when anti-drug antibodies have to be neutralised using more drug (i.e. non-linear kinetics). The latter phenomenon will lead to initial non-linear bDMARD clearance due to the presence of additional drug-binding proteins in the body, followed by linear pharmacokinetics when the surplus of these additional drug-binding proteins are all consumed. In fact, reversed MichaelisMenten pharmacokinetics occur, as the original Michaelis-Menten pharmacokinetics is characterised by initial linear pharmacokinetics, followed by non-linear pharmacokinetics due to saturation of the enzyme system [4].

\section{How much loading dose is needed?}

The amount of the loading dose is calculated by multiplying the desired peak concentration (Ctarget) by the volume of distribution of the drug $\left(\mathrm{V}_{\mathrm{D}}\right)$. In case of nonintravenous administration, the loading dose should also be corrected for the bioavailability (F) but it is mainly driven by the volume of distribution $\left(\mathrm{V}_{\mathrm{D}}\right)$ (loading dose $\left.=\left(C_{\text {target }} \times V_{d}\right) / F\right)$ [5]. This can cause practical problems with drugs with a high $V_{D}$, as the calculated 
Table 1 Overview of bDMARDs for AIRD, loading schedules (if applicable) and associated costs

\begin{tabular}{|c|c|c|c|c|c|c|c|}
\hline Drug class & Drug & $\begin{array}{l}\text { Terminal } \\
\text { halve life }\end{array}$ & $\begin{array}{l}\text { Authorised with } \\
\text { dose-loading in } \\
\text { AlRDs / other } \\
\text { disease? }\end{array}$ & Loading schedule & $\begin{array}{l}\text { Cost per patient } \\
\text { year with } \\
\text { loading dose }^{\mathbf{a}}\end{array}$ & $\begin{array}{l}\text { Cost per patient } \\
\text { year without } \\
\text { loading dose }\end{array}$ & $\begin{array}{l}\text { Euro/\% increase } \\
\text { medication costs due to } \\
\text { dose-loading for full year } \\
\text { use }\end{array}$ \\
\hline \multirow[t]{6}{*}{ TNFi } & Adalimumab & 14 days & No/Yes & NA & & & \\
\hline & Certolizumab & 14 days & Yes / NA & $\begin{array}{l}400 \text { mg weeks } 0,2, \\
4, \text { instead of } 200 \\
\text { mg }\end{array}$ & $€ 14,459$ & $€ 12,965$ & $€ 1495$ / 11.5\% \\
\hline & Etanercept & 3 days & No / Yes & NA & & & \\
\hline & Golimumab & 12 days & No / Yes & NA & & & \\
\hline & $\begin{array}{l}\text { Infliximab } \\
\text { (RA) }\end{array}$ & 9 days & Yes / Yes & $\begin{array}{l}3 \mathrm{mg} / \mathrm{kg} \text { weeks } 0,2, \\
6 \text { and } 14 \text {, instead } \\
\text { of } 8 \text { weekly }\end{array}$ & $€ 12,940$ & $€ 11,323$ & $€ 1617$ / 12.4\% \\
\hline & $\begin{array}{l}\text { Infliximab } \\
\text { (PsA/axSpA) }\end{array}$ & 9 days & Yes / Yes & $\begin{array}{l}5 \mathrm{mg} / \mathrm{kg} \text { weeks } 0,2, \\
6 \text { and } 14 \text {, instead } \\
\text { of } 8 \text { weekly }\end{array}$ & $€ 17,254$ & $€ 15,097$ & $€ 2157$ / 12.5\% \\
\hline Anti-CD20 & Rituximab & $\begin{array}{l}6-62 \\
\text { days }\end{array}$ & $\mathrm{No} / \mathrm{No}$ & NA & & & \\
\hline \multirow[t]{2}{*}{$\begin{array}{l}\text { Anti } \\
\text { CD80/86 }\end{array}$} & Abatacept i.v. & 14 days & Yes / No & $\begin{array}{l}750 \mathrm{mg} \text { weeks } 0,2,4 \\
\text { instead of weeks } 0 \text {, } \\
4^{\mathrm{c}}\end{array}$ & $€ 15,996$ & $€ 14,853$ & $€ 1143 / 7.1 \%$ \\
\hline & Abatacept s.c. & 14 days & Yes / NA & $\begin{array}{l}\text { Start with } 750 \mathrm{mg} \\
\text { i.v. instead of once } \\
\text { weekly } \mathrm{sc}^{\mathrm{c}}\end{array}$ & $€ 15,199$ & $€ 14,056$ & $€ 1143 / 7.5 \%$ \\
\hline $\begin{array}{l}\text { IL-1 } \\
\text { receptor } \\
\text { antagonist }\end{array}$ & Anakinra & $5 \mathrm{~h}$ & $\mathrm{No} / \mathrm{No}$ & NA & & & \\
\hline \multirow[t]{3}{*}{$\begin{array}{l}\text { Anti-IL6 } \\
\text { receptor }\end{array}$} & Sarilumab & $\begin{array}{l}9 \text { days } \\
\text { (initial) }\end{array}$ & $\mathrm{No} / \mathrm{No}$ & NA & & & \\
\hline & $\begin{array}{l}\text { Tocilizumab } \\
\text { i.v. }\end{array}$ & 3 days & $\mathrm{No} / \mathrm{No}$ & NA & & & \\
\hline & $\begin{array}{l}\text { Tocilizumab } \\
\text { s.c. }\end{array}$ & 13 days & $\mathrm{No} / \mathrm{No}$ & NA & & & \\
\hline \multirow[t]{3}{*}{$\begin{array}{l}\text { Anti-IL- } \\
17 \mathrm{~A}\end{array}$} & $\begin{array}{l}\text { Secukinumab } \\
150 \mathrm{mg}\end{array}$ & 27 days & Yes / Yes & $\begin{array}{l}\text { Weeks } 0,1,2,3,4 \\
\text { instead of monthly }\end{array}$ & $€ 9357$ & $€ 7486$ & $€ 1871 / 20 \%$ \\
\hline & $\begin{array}{l}\text { Secukinumab } \\
300 \mathrm{mg}\end{array}$ & 27 days & Yes / Yes & $\begin{array}{l}\text { Weeks } 0,1,2,3,4 \\
\text { instead of monthly }\end{array}$ & $€ 18,714$ & $€ 14,972$ & $€ 3742$ / 20\% \\
\hline & Ixekizumab & 13 days & Yes / Yes & $\begin{array}{l}160 \mathrm{mg} \text { instead of } \\
80 \mathrm{mg} \text { week } 0\end{array}$ & $€ 16,116$ & $€ 14,965$ & $€ 1151 / 7.1 \%$ \\
\hline $\begin{array}{l}\text { Anti-IL-12/ } \\
23\end{array}$ & Ustekinumab & 21 days & Yes / Yes & $\begin{array}{l}\text { Additional } \\
\text { injection at week } \\
4^{c}\end{array}$ & $€ 16,023$ & $€ 12,819$ & $€ 3204$ / 20\% \\
\hline
\end{tabular}

a www.medicijnkosten.nl, costs per patient year in the Netherlands

b $3 \mathrm{mg} /$ and $5 \mathrm{mg} / \mathrm{kg}$ rounded to $3^{*} 100 \mathrm{mg}$ and $4 * 100 \mathrm{mg}$ vials per infusion

c of the three weight based doses the middle dose of $750 \mathrm{mg}$ was used

c $45 \mathrm{mg}$ ( $<100 \mathrm{~kg}$ bodyweight) was used

Abbreviations: i.v. Intravenous, s.c. Subcutaneous, TNFi TNF inhibitor, AIRDs Auto-Immune Rheumatic Disease, NA Not Applicable, AIRD Auto-immune Rheumatic Diseases

loading dose to achieve steady-state concentration may be impractically large. This is clearly illustrated with digoxin $\left(\mathrm{T}_{1 / 2}: 30-40 \mathrm{~h}, \mathrm{~V}_{\mathrm{D}}: 83 \mathrm{l}\right.$ and $\mathrm{F}: 0,63$, Ctarget: $0,8-2$, $0 \mu \mathrm{g} / \mathrm{l})$ : Based on the formula an initial oral dose of $740 \mu \mathrm{g}$ is needed, but this has a relative high risk of side effects, and slow digitalization is warranted. Calculating the needed loading dose is even more complicated when loading is not applied for a pure pharmacological reason, but to compensate for loss of the drug or high drug consumptions in the early treatment phase, such as described above.

\section{The disadvantages of a loading dose}

Despite the earlier achievement of Css, giving loading doses also has disadvantages. For example, sensitive individuals might abruptly be exposed to toxic concentrations 
and it can take a long time to reach lower concentrations when the drug has a long half-life. Furthermore, the need for both loading and maintenance doses creates complexity in prescribing, dispensing, administration, and monitoring of medication and this complexity increases the likelihood of human error. In the National Reporting and Learning System (NRLS), the use of loading doses indeed is associated with safety incidents $[6,7]$.

Exposure to more drug might also result in more bDMARD-related side effects such as infections. A review of Singh et al. [8] showed that infection risks are dose dependent, with higher risks in patients receiving supra-authorised dosing compared to standard dosing or sub- authorised dosing. The effects of loading doses were not included in the review of Sing and colleagues, unfortunately. However, as loading doses aim at reaching Css at an earlier stage, and not at increasing Cmax or Cavg (i.e. average plasma concentration at steady state) specifically, the increased infection risk may be minimal.

\section{Dose loading of bDMARDs}

bDMARDs are large molecular weight $(150 \mathrm{kDa})$ hydrophilic molecules which distribute predominantly in to lymphatic and blood vessels. Small amounts of bDMARDs also penetrate into the cells via fluid phase endocytosis or via receptor-mediated endocytosis via the (mostly neonatal) FcyR expressed on the membrane of immunological cells [9]. As a consequence, central volumes of distribution are small, approximately ranging from 2.4 to 6.51 [4].

The half-lives of bDMARDs, however, vary widely from $70 \mathrm{~h}$ (etanercept) to $540 \mathrm{~h}$ (sarilumab). Inherently, the time to achieve an effective concentration and steady state also varies from days to weeks. From a purely pharmacokinetic perspective, dose loading can be used to shorten the time between the start of therapy and the timepoint when the minimal effective concentration is achieved, thus also achieving the pharmacodynamic effect and clinical response earlier. Given the relatively small volume of distribution, 1-2 additional regular doses as loading dose should be sufficient.

\section{Clinical evidence on the efficacy of dose loading of bDMARDs on disease activity in patients with AIRDs \\ Methods}

For studying clinical evidence on the efficacy of dose loading of bDMARDs on disease activity in patients with AIRDs, we systematically searched Pubmed / Medline, the Cochrane database, and clinicaltrials.gov to identify relevant studies until October 1st, 2018. Because of the anticipated lack of studies with high methodological quality, we aimed at including randomised controlled trials as well as other controlled studies with at least two treatment groups (i.e. with and without loading doses). A loading dose was defined as higher dosing during the first weeks of treatment compared to the period afterwards.

Eligible studies were performed with humans of at least 18 years of age, are written in English, with at least 20 patients with a follow-up of at least 3 months. The most commonly used biological agents, defined as receptor constructs or fusion proteins (suffix -cept), monoclonal antibodies (suffix -mab), and receptor antagonists (suffix -ra) approved for auto-immune rheumatic diseases (AIRDs; i.e. Rheumatoid Arthritis (RA), spondylarthropathies (Psoriatic Arthritis (PsA), spondyloarthropathies $(\mathrm{SpA})$ ) by the FDA and/or the EMEA, were included for review, which were: TNFi's (infliximab, etanercept, adalimumab, certolizumab pegol, golimumab), anti CD20 (rituximab), anti-CD80/86 (abatacept), IL-1 receptor antagonist (anakinra), IL-6 inhibitors (sarilumab, tocilizumab), IL-17 inhibitors (secukinumab, ixekizumab), and anti-IL-12/23 (ustekinumab). Studies on dose loading of bDMARDs in other conditions than AIRD were excluded (see Appendix A).

Identified references were independently screened for eligibility by title and abstract by two reviewers (GG, LV). Full text papers were then used to decide on eligibility. In case of discrepancies, a third reviewer (AB) was consulted. The reference lists of included articles were then studied to further identify relevant papers (snowballing). Conference proceedings and reports of meetings were also considered for inclusion. Search strings and strategies are provided in Appendix A.

Data on patient population, sample size, study design, dosing regimens, main outcome measures, and secondary outcome measures / safety issues were extracted from the selected papers. We did not plan a formal quantitative meta-analysis because of the anticipated clinical heterogeneity and low numbers of included studies per drug.

\section{Results}

Results from the search procedures are listed in Fig. 1.

Five studies were included in this review; four full text journal articles and one conference abstract. The selected studies were published between 2011 and 2018. Two [10, 11] comprised post hoc analyses of previously performed large trials. The other three studies [12-14] were randomised controlled trials. Two were performed on PsA [12, 13], two on RA $[10,11]$, and one on SpA (Ankylosing Spondylitis, AS) [14]. Two studies described the effect of dose loading of abatacept [11, 12], one of certolizumab pegol [10], and two of secukinumab [13, 14]. Table 2 lists the main findings for each of these studies. 


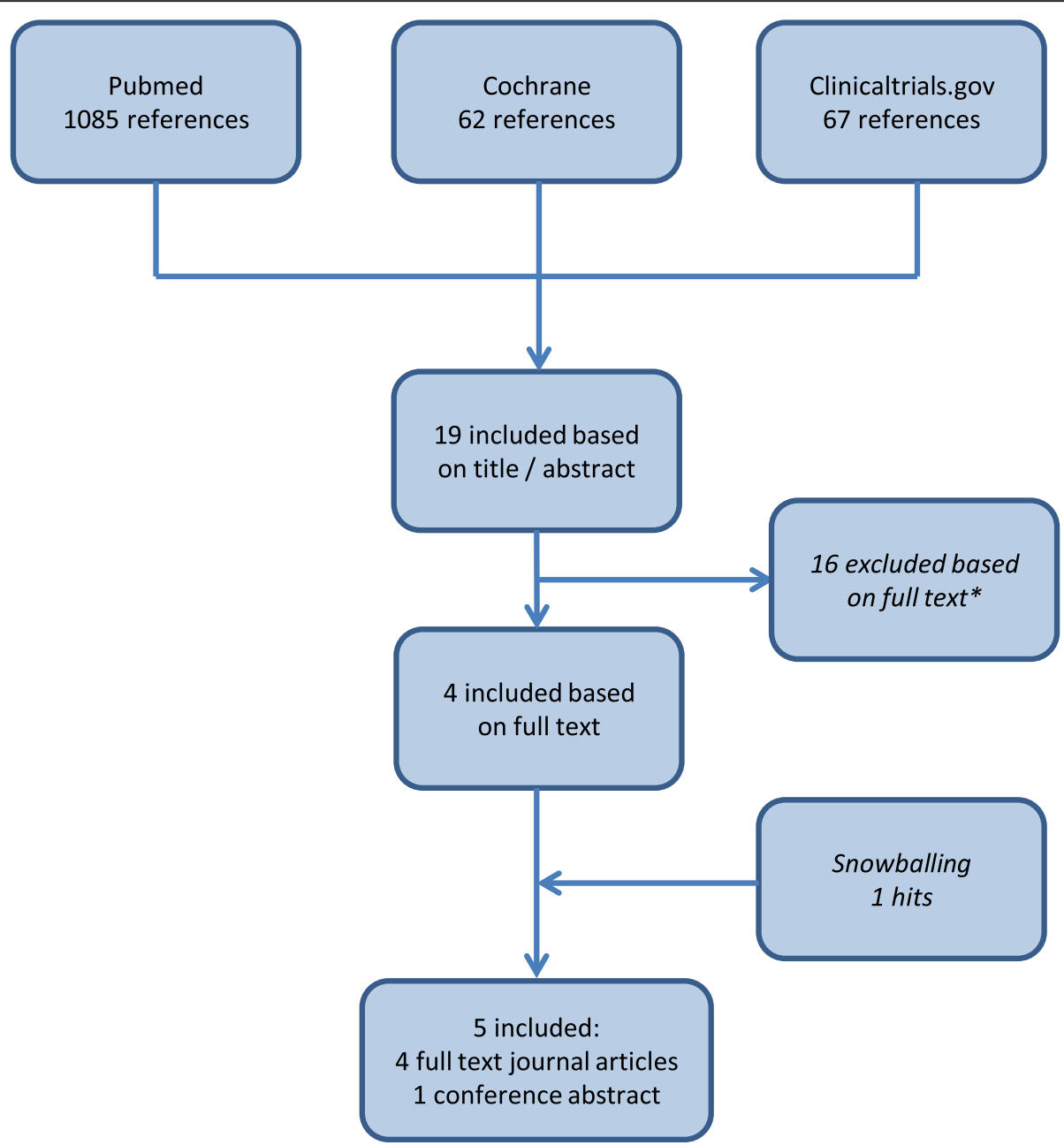

Fig. 1 Search results and inclusion. * Reasons for exclusion: no comparison loading dose versus no loading dose $(n=15)$, (pharmacodynamic/ -kinetic) modelling studies instead of real data $(n=2)$ and a narrative review $(n=1)$

\section{Primary outcome: ACR20 / ASAS20}

Primary outcome measure was the ACR20 response in four of the five studies. and ASAS20 in the remaining study. For abatacept, different loading dose regimens were applied. In the study of Mease et al. [12], loading was performed by dosing $(3 \mathrm{mg} / \mathrm{kg}, 10 \mathrm{mg} / \mathrm{kg}$, or $30 \mathrm{mg} /$ $\mathrm{kg}$ ) every 2 weeks for the first 3 times, followed by 3,10 and $10 \mathrm{mg} / \mathrm{kg}$ four-weekly respectively. Schiff et al. [11] added a single dose of $10 \mathrm{mg} / \mathrm{kg}$ intravenously at day one, followed by a $125 \mathrm{mg} /$ week subcutaneous dose. For patients with PsA loading was reported not to enhance efficacy in terms of ACR20 response compared to without loading dose [12]. Comparably, in RA, loading appeared not to affect time to onset and magnitude of ACR20 response [11].

For certolizumab pegol only one study was included [11], evaluating the ACR20 response at week 16 in patients with RA with and without loading dose of $400 \mathrm{mg}$ at weeks 0 , 2, and 4, with regular doses of $200 \mathrm{mg}$ every other week afterwards. The ACR20 response in patients with a loading dose seemed (numerically) to be achieved faster and sustained until 24 weeks follow-up compared to those receiving no loading dose (no data on statistical significance reported).

In two studies, secukinumab was dosed $150 \mathrm{mg} \mathrm{sc}$ every 4 weeks starting at week 0 , with loading doses at weeks 1, 2, and 3 compared to patients without loading dose. In patients with PsA [13] or with AS [14], loading did not contribute to improved outcome in terms of ACR20 response at 16 weeks compared to no loading.

\section{Secondary outcomes and safety issues}

Secondary outcomes were abundantly reported in these studies. For the studies reporting on abatacept, improvements were described on secondary outcome measures compared to placebo, but no statistical difference was observed between the groups receiving a loading dose compared to the group not receiving a loading dose. For 
Table 2 Included references and results

\begin{tabular}{|c|c|c|c|c|c|c|c|c|c|}
\hline Reference & $\begin{array}{l}\text { Patient } \\
\text { population }\end{array}$ & Study design & Drug & $\begin{array}{l}\text { Groups and } \\
\text { dosing } \\
\text { regimens }\end{array}$ & $\begin{array}{l}\text { Numbers } \\
\text { of } \\
\text { patients }\end{array}$ & $\begin{array}{l}\text { Primary } \\
\text { outcome }\end{array}$ & $\begin{array}{l}\text { Results } \\
\text { primary } \\
\text { outcome }\end{array}$ & $\begin{array}{l}\text { Relevant } \\
\text { secondary } \\
\text { outcomes }\end{array}$ & $\begin{array}{l}\text { Results secondary } \\
\text { outcomes }\end{array}$ \\
\hline $\begin{array}{l}\text { Mease } \\
\text { et al., } 2011 \\
\text { [12] }\end{array}$ & $\begin{array}{l}\text { Psoriatic } \\
\text { Arthritis }\end{array}$ & $\begin{array}{l}\text { Randomized, } \\
\text { double-blind, } \\
\text { placebo- } \\
\text { controlled } \\
\text { Phase II trial }\end{array}$ & Abatacept & $\begin{array}{l}\text { Group } 1: 3 \\
\mathrm{mg} / \mathrm{kg} \text { at } \\
\text { days } 1,15, \\
\text { and } 29 \text {, every } \\
4 \text { weeks } \\
\text { thereafter } \\
\text { Group } 2: 10 \\
\mathrm{mg} / \mathrm{kg} \text { at } \\
\text { days } 1,15, \\
\text { and } 29, \text { every } \\
4 \text { weeks } \\
\text { thereafter } \\
\text { Group } 3: 30 \\
\text { mg/kg at } \\
\text { days } 1 \text { and } \\
15,10 \mathrm{mg} / \mathrm{kg} \\
\text { at day } 29 \text { and } \\
\text { every } 4 \text { weeks } \\
\text { thereafter }^{\mathrm{a}}\end{array}$ & $\begin{array}{l}\text { Group 1: } \\
43 \\
\text { Group 2: } \\
40 \\
\text { Group 3: } \\
45\end{array}$ & $\begin{array}{l}\text { ACR20 } \\
\text { at } 6 \\
\text { months }\end{array}$ & $\begin{array}{l}\text { ACR20 } \\
\text { Group 1: } \\
\text { 33\% } \\
\text { Group 2: } \\
\text { 48\% } \\
\text { Group 3: } \\
\text { 42\% } \\
\text { No } \\
\text { significant } \\
\text { differences } \\
\text { reported } \\
\text { between the } \\
\text { groups } \\
\text { (especially } \\
\text { groups 2 } \\
\text { and 3) }\end{array}$ & $\begin{array}{l}\text { HAQ-DI } \\
\text { SF-36 } \\
\text { ACR50 } \\
\text { ACR70 } \\
\text { Damage of } \\
\text { joints on MRI } \\
\text { AE's }\end{array}$ & $\begin{array}{l}\text { No significant } \\
\text { differences } \\
\text { reported between } \\
\text { the groups } \\
\text { (especially groups } \\
2 \text { and } 3 \text { ) }\end{array}$ \\
\hline $\begin{array}{l}\text { Schiff et al., } \\
\text { ACR } \\
\text { meeting } \\
2012[11]\end{array}$ & $\begin{array}{l}\text { Rheumatoid } \\
\text { Arthritis }\end{array}$ & $\begin{array}{l}\text { Randomized } \\
\text { study; post- } \\
\text { hoc analysis } \\
\text { on data from } \\
\text { the ACQUIRE } \\
\text { and AMPLE } \\
\text { studies }\end{array}$ & Abatacept & $\begin{array}{l}\text { Group 1: s.c. } \\
125 \mathrm{mg} / \text { week } \\
\text { (ACQUIRE) } \\
\text { Group 2: s.c. } \\
125 \mathrm{mg} / \text { week, } \\
\text { plus i.v. } \\
\text { loading dose } \\
10 \mathrm{mg} / \mathrm{kg} \text { on } \\
\text { day } 1 \text { (AMPLE) }\end{array}$ & $\begin{array}{l}\text { Group 1: } \\
736 \\
\text { (ACQUIRE) } \\
\text { Group 2: } \\
318 \\
\text { (AMPLE) }\end{array}$ & $\begin{array}{l}\text { ACR20 } \\
\text { at weeks } \\
2,4,8 \\
12,16 \\
20,24\end{array}$ & $\begin{array}{l}\text { ACR20 at } \\
\text { weeks 2, 4, } 8 \text {, } \\
\text { 12, 16, 20, } 24 \\
\text { Group 1: } \\
\text { 27.4, 42.5, } \\
\text { 58.5, 60.1, } \\
66.0,70.1 \text {, } \\
66.0 \% \\
\text { Group 2:24.6, } \\
\text { 44.5, 58.0, } \\
66.6,69.3 \text {, } \\
\text { 72.4, 74.8\% } \\
\text { No } \\
\text { significant } \\
\text { difference } \\
\text { between the } \\
\text { groups }\end{array}$ & $\begin{array}{l}\text { HAQ-DI at } \\
\text { weeks } 2,4,8, \\
12,16,20,24 \\
\text { Changes in } \\
\text { DAS28 CRP } \\
\text { from baseline } \\
\text { over } 6 \text { months }\end{array}$ & $\begin{array}{l}\text { No significant } \\
\text { difference } \\
\text { between the } \\
\text { groups }\end{array}$ \\
\hline $\begin{array}{l}\text { Takeuchi } \\
\text { et al., Mod } \\
\text { Rheumatol } \\
2016 \text { [10] }\end{array}$ & $\begin{array}{l}\text { Rheumatoid } \\
\text { Arthritis }\end{array}$ & $\begin{array}{l}\text { Open label } \\
\text { extension } \\
\text { study; post } \\
\text { hoc analysis } \\
\text { of the J- } \\
\text { RAPID and } \\
\text { HIKARI trials }\end{array}$ & $\begin{array}{l}\text { Certolizumab } \\
\text { pegol (CZP) }\end{array}$ & $\begin{array}{l}\text { Group 1: } 400 \\
\text { mg loading } \\
\text { dose at weeks } \\
\text { 0, 2, and 4, } \\
\text { then } 200 \text { mg } \\
\text { Q2W } \\
\text { thereafter } \\
\text { Group 2: } 200 \\
\text { mg Q2W }\end{array}$ & $\begin{array}{l}\text { Group 1: } \\
198 \\
\text { Group 2: } \\
160\end{array}$ & $\begin{array}{l}\text { ACR20 } \\
\text { at weeks } \\
4,8,12, \\
16,20, \\
24 \% \\
\text { Low } \\
\text { disease } \\
\text { activity }\end{array}$ & $\begin{array}{l}\text { ACR20 at } \\
\text { week 4 } \\
\text { Group 1: } \\
62.2 \text { and } \\
67.2 \% \\
\text { Group 2: } \\
57.1 \text { and } \\
49.5 \% \\
\text { ACR20 at } \\
\text { week } 8 \\
\text { Group 1: } \\
82.9 \text { and } \\
71.6 \% \\
\text { Group 2: } \\
69.6 \text { and } \\
61.1 \% \\
\text { Absolute } \\
\text { values for } \\
\text { week 12, 16, } \\
\text { 20, and 24 } \\
\text { were not } \\
\text { provided; } \\
\text { graphical } \\
\text { presentation } \\
\text { only. } \\
\text { No statistical } \\
\text { data } \\
\text { provided }\end{array}$ & $\begin{array}{l}\text { Not well } \\
\text { defined in } \\
\text { methods } \\
\text { section, but } \\
\text { reported for: } \\
\text { ACR50,70 } \\
\text { responses } \\
\% \text { Low disease } \\
\text { activity (LDA) } \\
\text { at weeks } 12 \\
\text { and } 24 \\
\text { Plasma } \\
\text { concentrations } \\
\text { of CZP and } \\
\text { antibodies } \\
\text { against CZP } \\
\text { Adverse Events } \\
\text { rates }\end{array}$ & $\begin{array}{l}\text { Loading dose } \\
\text { groups showed } \\
\text { faster ACR } \\
\text { responses } \\
\text { followed by } \\
\text { sustained ACR } \\
\text { responses up to } \\
24 \text { weeks } \\
\text { compared to } \\
\text { patients who did } \\
\text { not receive } \\
\text { loading dose. } \\
\text { Higher levels of } \\
\text { antibodies in } \\
\text { group without } \\
\text { loading dose. } \\
\text { Similar adverse } \\
\text { event rates. } \\
\text { No statistical data } \\
\text { provided. }\end{array}$ \\
\hline Mease & Psoriatic & Randomised & Secukinumab & Group 1: & Group 1: & ACR20 & ACR20 & Radiographic & No statistical \\
\hline
\end{tabular}


Table 2 Included references and results (Continued)

\begin{tabular}{|c|c|c|c|c|c|c|c|c|c|}
\hline Reference & $\begin{array}{l}\text { Patient } \\
\text { population }\end{array}$ & Study design & Drug & $\begin{array}{l}\text { Groups and } \\
\text { dosing } \\
\text { regimens }\end{array}$ & $\begin{array}{l}\text { Numbers } \\
\text { of } \\
\text { patients }\end{array}$ & $\begin{array}{l}\text { Primary } \\
\text { outcome }\end{array}$ & $\begin{array}{l}\text { Results } \\
\text { primary } \\
\text { outcome }\end{array}$ & $\begin{array}{l}\text { Relevant } \\
\text { secondary } \\
\text { outcomes }\end{array}$ & $\begin{array}{l}\text { Results secondary } \\
\text { outcomes }\end{array}$ \\
\hline $\begin{array}{l}\text { et al., Ann } \\
\text { Rheum Dis, } \\
2018 \text { [13] }\end{array}$ & Arthritis & $\begin{array}{l}\text { double-blind } \\
\text { phase III FU- } \\
\text { TURE } 5 \text { study }\end{array}$ & & $\begin{array}{l}150 \text { mg s.c. } \\
\text { with loading } \\
\text { dose, at } \\
\text { weeks 0, 1, 2, } \\
3 \text { and 4, then } \\
\text { every } 4 \text { weeks } \\
\text { thereafter } \\
\text { Group 2: } 150 \\
\text { mg s.c. } \\
\text { without } \\
\text { loading dose, } \\
\text { at weeks } 0, \text { (at } \\
\text { 1, 2, } 3 \\
\text { placebo) and } \\
4, \text { then every } \\
4 \text { weeks } \\
\text { thereafter }{ }^{a}\end{array}$ & $\begin{array}{l}222 \\
\text { Group 2: } \\
220\end{array}$ & $\begin{array}{l}\text { at week } \\
16\end{array}$ & $\begin{array}{l}\text { response at } \\
\text { week } 16 \\
\text { Group 1: } \\
55.5 \% \\
\text { Group 2: } \\
59.5 \% \\
\text { No statistical } \\
\text { difference } \\
\text { between } \\
\text { loading } \\
\text { versus no } \\
\text { loading }\end{array}$ & $\begin{array}{l}\text { progression at } \\
\text { week } 24 \text { (van } \\
\text { der Heijde- } \\
\text { modified total } \\
\text { Sharp score) } \\
\text { HAQ-DI } \\
\text { DAS28-CRP } \\
\text { ACR50/70 } \\
\text { response } \\
\text { Proportion of } \\
\text { patients } \\
\text { achieving MDA } \\
\text { at week } 16 \\
\text { AE's and SAE's }\end{array}$ & $\begin{array}{l}\text { difference } \\
\text { between loading } \\
\text { versus no loading }\end{array}$ \\
\hline $\begin{array}{l}\text { Kivitz et al., } \\
\text { Rheumatol } \\
\text { Ther, } 2018 \\
\text { [14] }\end{array}$ & $\begin{array}{l}\text { Ankylosing } \\
\text { Spondylitis }\end{array}$ & $\begin{array}{l}\text { Randomized } \\
\text { placebo } \\
\text { controlled } \\
\text { trial } \\
\text { MEASURE } 4 \\
\text { study }\end{array}$ & Secukinumab & $\begin{array}{l}\text { Group 1: } 150 \\
\text { mg at week } 0 \\
\text { and every } 4 \\
\text { weeks } \\
\text { thereafter, } \\
\text { with loading } \\
\text { dose } 150 \text { mg } \\
\text { at weeks 1, 2, } \\
\text { and } 3 \\
\text { Group 2: } 150 \\
\text { mg at week } 0 \\
\text { and every } 4 \\
\text { weeks } \\
\text { thereafter, } \\
\text { with placebo } \\
\text { at weeks 1, 2, } \\
\text { and } 3\end{array}$ & $\begin{array}{l}\text { Group 1: } \\
116 \\
\text { Group 2: } \\
117\end{array}$ & $\begin{array}{l}\text { ASAS20 } \\
\text { at } 16 \\
\text { weeks }\end{array}$ & $\begin{array}{l}\text { ASAS20 at } \\
16 \text { weeks } \\
\text { Group 1: } \\
59.5 \% \\
\text { Group 2: } \\
61.5 \% \\
\text { No } \\
\text { significant } \\
\text { difference. }\end{array}$ & $\begin{array}{l}\text { ASAS20 at 52, } \\
\text { and } 104 \text { weeks } \\
\text { ASAS40 at } 16 \\
\text { weeks } \\
\% \text { achieving } \\
\text { ASAS20 and } \\
\text { ASAS40 } \\
\text { Change from } \\
\text { baseline in } \\
\text { BASDAI \% AEs, } \\
\% \text { SAEs }\end{array}$ & $\begin{array}{l}\text { No significant } \\
\text { difference }\end{array}$ \\
\hline
\end{tabular}

\footnotetext{
a Placebo groups were removed from the table $[12,13]$
}

${ }^{b}$ Exact patient numbers in each group at each time point could not be extracted from the manuscript for post hoc statistical analysis Abbreviations:

ACR American College of Rheumatology (ACR20 means $20 \%$ improvementin tender or swollen joint counts as well as $20 \%$ improvement in three of the other five criteria; ACR50 70 analogous)

HAQ-DI Health Assessment Questionnaire, Disability Index

SF36 Short Form 36

ASAS Assessment in Spondyloarthritis International Society

Q2W Every two weeks

DAS28 CRP Disease Activity Score based on 28 joints and C-reactive protein

$B A S D A /$ Bath Ankylosing Spondylitis Disease Activity Index

MDA Minimal Disease Activity

(S)AE (Serious) Adverse Events

CZP Certolizumab pegol

certolizumab pegol, lower antibodies levels were found in those receiving a loading dose. No differences were found in the secondary outcome measures reported between those who did and did not receive loading doses of secukinumab.

(Serious) Adverse Event rates were low. None of the five studies reported statistically significant differences when comparing loading versus no loading.

\section{Discussion and conclusions}

This paper highlights two important aspects of dose loading of bDMARDs in AIRDs. First, dose loading seems to be a sensible approach from a pharmacokinetic perspective. However, hardly any clinical evidence has been published on this topic, and studies that did address this topic were heterogeneous in terms of patient population and drug under investigation, and generally from moderate methodological quality. Safety profiles seem favorable, but, again, data is scarce. As a consequence, evidence on superiority in terms of disease activity compared to a dosing regimen without loading is lacking, although safety profiles may .

The small number of studies identified comparing regimens with dose loading to regimens without, does not seem to be caused by a suboptimal search, as broad criteria were used and a systematic search was done in the 
main scientific medical databases without limits on the date of publication. This review being narrative systematic or scoping in nature, we decided to systematically search a limited number of databases. From this perspective, we chose not to include the EMBASE database. It is unlikely that searching EMBASE would have changed the conclusions of this paper, especially since the level of agreement with Pubmed/Medline, the Cochrane database, and clinicaltrial.gov is considerable, and we used the snowballing technique to identify papers that might have been missed in the performed searches or might only have been found in other databases. We could have expanded the number of selected studies for this review if we had included pharmacokinetic / -dynamic (PK / PD) modelling studies on dose loading. For example, Ternant and colleagues [15] suggested after PK / PD modelling that dose loading of adalimumab may lead to increased benefit for patients with RA. These modelling studies provide indirect evidence for clinical efficacy and provide inspiring new insights and ideas for clinical research, but they do not, however, prove clinical efficacy. Other sources of indirect evidence favoring dose loading are drug plasma concentrations and antibody studies, sometimes with short term efficacy. Yamamoto et al. [16] reported lower antibodies to certolizumab pegol in patients receiving a loading dose compared to those who did not. However, no statistical evidence for this statement was provided. In patients with Crohn's disease treated with a loading dose of adalimumab, Karmiris et al. [17] reported higher trough concentrations after 4 weeks after starting treatment, less frequent nonresponse, and longer sustained benefit than the patients who did not receive a loading dose. However, although lower antibody levels and higher plasma concentrations and better 4 week clinical efficacy are promising results, in our view clinical efficacy at weeks 12 and 24 is a more relevant clinical outcome. Also, this study included patients not with AIRD, but with inflammatory bowel diseases (IBD). Summarizing, PK / PD (modelling) studies report indirect evidence and whether these findings can be translated to better clinical outcome remains unclear. For this reason, these studies were not included in the current review.

Our work focused on AIRDs alone and the question is whether the effects of dose loading are comparable to other disease entities in which bDMARDs are prescribed, such as in psoriasis, IBD, or ophthalmological conditions. In psoriasis, for example, a review has been performed describing the efficacy and safety of dose loading of etanercept and adalimumab [18]. This study concluded that for etanercept dose loading resulted in more rapid and higher percentages of patients showing skin improvements, while for adalimumab there was insufficient evidence. In Crohn's disease, the additional benefit of a loading dose of $160 \mathrm{mg}$ adalimumab has been demonstrated in several studies [17-19], and this regimen is also recommended by the FDA. Dose loading may thus be more appropriate in non-AIRDs than in rheumatic inflammatory diseases. This may be explained by essential pathophysiological and background treatment differences. For example, in IBD the bioavailability of the drug might sometimes be lower due to protein losing enteropathy. The total inflammatory load might also be different between AIRDs and other conditions, especially when comparing RA with IBD, necessitating more drug in the active initial phase. Finally, in RA, a bridging treatment is performed using glucocorticoids orally or intramuscularly, This bridging reduces symptoms of AIRDs rapidly, and is especially relevant in the light of the 'window of opportunity'. This window represents a timeframe in which the disease is potentially amenable and may be reset; aggressive therapy administered in this window can slow the rate of structural damage at long term [20]. Bridging with glucocorticoids negates a possible effect of dose loading, and is proven efficacious and less expensive. However, initial glucocorticoids treatment has not formally been used in the clinical studies we identified, and also, in IBD this is applied at least as frequent as in RA and more than in SpA. When summarizing the considerations above, the rationale for dose loading in AIRDs seems absent, but for IBD or psoriasis it might be a beneficial strategy.

Dose loading aims at achieving Css at an earlier state, and not increasing the maximal or average plasma concentration at steady state. This implies that safety issues were assumed not to be a major concern in dose loading. Indeed, we did not identify significantly increased adverse events in this review. Although large scale data between treatment strategies with or without dose loading are absent, similar results were reported for dose loading of adalimumab in Crohn's disease [19], further supporting our assumption of its safety.

Besides considering clinical evidence and safety, another important issue is the economic aspect of dose loading. To our knowledge, no cost effectiveness or budget impact analyses comparing biological treatment with and without dose loading have been performed. Hypothetically, there are two effects in which dose loading might contribute to higher cost and (with equal effectiveness) lower cost effectiveness. Firstly, the loading dose itself leads to increased medication use and cost. The magnitude of this is an increase between 7.1 and $20 \%$ for loading compared to no loading, for the first full year of treatment compared to subsequent years (as can be derived from Table 1). Although this increase in cost regresses when the patient stays on the drug longer than the first year, this is a limited effect while there is a substantial amount of patient who stop the drug after for 
example 3 to 6 months of use due to lack of efficacy or adverse effects. Recent developments in state of art bDMARD care, such as treat to target, will further shorten drug survival and herewith further increase the relative cost impact of dose loading. Secondly, dose loading might also lead to more 'dose creep'. This is the effect that health care providers increase the dose in nonresponding patients above the authorised and maximum effective dose [21]. Although this is not effective and indeed not officially endorsed, the phenomenon has been well recognised. Further research on this topic is warranted including a comprehensive cost-effectiveness analysis. These results are needed for evidence based recommendations with regard to dose loading.

In conclusion, although dose loading seems reasonable from a pharmacodynamic / - kinetic perspective, there is insufficient evidence on its superiority in terms of disease activity compared to a dosing regimen without loading. Data on cost-effectiveness of these regimens have not been published, while safety issues might be comparable. More research on this topic is urgently needed, based on which authorities may reconsider reimbursement of dose loading regimens to further encourage evidence based practice.

\section{Supplementary information}

Supplementary information accompanies this paper at https://doi.org/10. 1186/s41927-020-00130-x.

\section{Additional file 1}

\section{Acknowledgements}

Not applicable.

\begin{abstract}
Authors' contributions
LV and GG performed the database searches and selected eligible articles from these searches. LV and GG wrote the sections on clinical evidence on the efficacy of dose loading of bDMARDs on disease activity in patient with AIRDs. BB wrote the section on the rationale of dose loading of bDMARDs in AIRDs from a pharmacokinetic / - dynamic perspective, and AB wrote the section on (pharmaco-) Economic consequences of dose-loading. All authors contributed to the background and discussion sections. The authors have read and approved the manuscript.
\end{abstract}

\section{Funding}

No funding was obtained for this study.

\section{Availability of data and materials \\ Not applicable.}

Ethics approval and consent to participate

Not applicable.

\section{Consent for publication}

Not applicable.

\section{Competing interests}

GG: No disclosures.

LV: No disclosures.

BvdB: Received grant/research support from: UCB, Pfizer, Abbvie, BristolMyers Squibb; Speakers bureau: Pfizer, AbbVie, UCB, Biogen, Sandoz. Delivered consultancy work for UCB, Novartis and Pfizer.
AdB: Investigator for BMS (abatacept), received grants from Biogen, Sanofi and Abbvie. Advisor College ter Beoordeling Geneesmiddelen Netherlands (CBG). Advisor ReumaNederland / Dutch Arthritis foundation scientific advisory board. EULAR RA recommendations member. Several investigator initiated, publicly funded, pharmaceutical trials studying tofacitinib (PRACTICAL study), rituximab (REDO and.

BRIDGE PMR study), TNF inhibitors (DRESS-PS study), MTX and leflunomide (COMPLETE-PSA study), MTX in PMR (PMR-MTX study).

\section{Author details}

'Department of Rheumatology, Sint Maartenskliniek, PO Box 9011, 6500, GM, Nijmegen, The Netherlands. '2Department of Pharmacy, Sint Maartenskliniek, PO Box 9011, 6500, GM, Nijmegen, The Netherlands. ${ }^{3}$ Department of Pharmacy, Radboudumc, Nijmegen, The Netherlands. ${ }^{4}$ Department of Rheumatology, Radboudumc, Nijmegen, The Netherlands.

Received: 27 October 2019 Accepted: 2 April 2020

Published online: 28 July 2020

\section{References}

1. Singh JA, Wells GA, Christensen R, et al. Adverse effects of biologics: a network meta-analysis and cochrane overview. Cochrane Database Syst Rev. 2011;2:CD008794.

2. Chastek B, White J, Van Voorhis D, Tang D, Stolshek BS. A retrospective cohort study comparing utilization and costs of biologic therapies and JAK inhibitor therapy across four common inflammatory indications in adult US managed care patients. Adv Ther. 2016;33:626-42.

3. Brunton LL, Chabner BA, Knollmann BC. In: Goodman, Gilman's, editors. The Pharmacological Basis of therapeutics. 12th ed. New York: McGraw Hill; 2011. p. 17

4. Ternant D, Bejan-Angoulvant T, Passot C, Mulleman D, Paintaud G. Clinical pharmacokinetics and pharmacodynamics of monoclonal antibodies approved to treat rheumatoid arthritis. Clin Pharmacokinet. 2015;11:1107-23.

5. Rowland M, Tozer TN. Clinical Pharmacokinetics and Pharmacodynamics. 4th ed. Philadelphia: Wolters Kluwer; 2011.

6. National Patient Safety Agency (NPSA). Rapid Response Report: Preventing fatalities from medication loading doses. 2010; RRR018.

7. Lamont L, Cousins D, Bischler A, Gerrett D. Safer loading doses of medicines: summary of a safety report from the National Patient Safety Agency. BMJ. 2011;342:d33

8. Singh JA, Cameron C, Noorbacloochi S, et al. Risk of serious infection I biological treatment of patients with rheumatoid arthritis: a systematic review and meta-analysis. Lancet. 2015;18(386):358-65.

9. Dirks NL, Meibohm B. Population pharmacokinetics of therapeutic monoclonal antibodies. Clin Pharmacokinet. 2010;49:633-59.

10. Takeuchi T, Yamamoto K, Yamanaka H, et al. Post hoc analysis showing better clinical response with the loading dose of certolizumab pegol in Japanese patients with active rheumatoid arthritis. Mod Rheumatol. 2016; 26(4):473-80.

11. Schiff $M$, Alten $R$, Weinblatt, et al. Weekly subcutaneous abatacept confers comparable onset of treatment response and magnitude of efficacy improvement over 6 months when administered with or without and intravenous abatacept loading dose. In: ACR / ARHP Annual meeting; 2012. abstract number 2547.

12. Mease P, Genovese MC, Gladstein G, et al. Abatacept in the treatment of patients with psoriatic arthritis. Arthritis Rheum. 2011:63(4):939-48.

13. Mease $P$, van der Heijde $D$, Landewé $R$, et al. Secukinumab improves active psoriatic arthritis symptoms and inhibits radiographic progression: primary results from the randomised, double-blind, phase III FUTURE 5 study. Ann Rheum Dis. 2018;77:890-7.

14. Kivitz AJ, Wagner U, Dokoupilova SJ, et al. Efficacy and safety of secukinumab 150 mg wit hand without loading regimen in ankylosing spondylitis: 104-week results from MEASURE 4 study. Rheumatol Ther. 2018. https://doi.org/10.1007/s40744-018-0123-5.

15. Ternant $D$, Ducourau $E$, Fuzibet $P$, Vignault $C$, Watier $H$, Leguerré $T$, Le Loët X, Vitecoq O, Goupille P, Mulleman D, Paintaud G. Pharmacokinetics and concentration-effect relationships of adalimumab in rheumatoid arthritis. $\mathrm{Br}$ J Clin Pharmacol. 2015;79(2):286-97.

16. Yamamoto $K$, Takeuchi $T$, Yamanaka $H$, et al. Efficacy and safety of certolizumab pegol without methotrexate co-administration in Japanese 
patients with active rheumatoid arthritis: the HIKARI randomized, placebocontrolled trial. Mod Rheumatol. 2014;24(4):552-60.

17. Karmiris K, Paintaud G, Noman M, Magdelaine-Beuzelin C, Ferrante M, Degenne D, Claes K, Coopman T, Van Schuerbeek N, Van Assche G,

Vermeire $S$, Rutgeerts P. Influence of trough serum levels and immunogenicity on long-term outcome of adalimumab therapy in Crohn's disease. Gastroenterology. 2009;137:1628-40.

18. Gilbert KE, Manalo IF, Wu JJ. Efficay and safety of etanercept and adalimumab with and without loading dose for psoriasis; a systematic review. J Am Acad Dermatol. 2015;73(2):329-31.

19. Hanauer SB, Sandborn WJ, Rutgeerts P, Fedorak RN, Lukas M, Maclntosh D, Panaccione R, Wolf D, Pollack P. Human anti-tumor necrosis factor monoclonal antibody (adalimumab) in Crohn's disease: the CLASSIC-I trial. Gastroenterology. 2006;130:323-33.

20. Landewe RB, Boers $M$, Verhoeven $A C$, et al. COBRA combination therapy in patients with early rheumatoid arthritis: long-term structural benefits of a brief intervention. Arthritis Rheum. 2002;46:347-56.

21. Martin K, Lott S. Dose creep and biologic therapies: pharmacists' role in optimizing therapy. Pharmacy Today. 2017;23(10):44.

\section{Publisher's Note}

Springer Nature remains neutral with regard to jurisdictional claims in published maps and institutional affiliations.

Ready to submit your research? Choose BMC and benefit from:

- fast, convenient online submission

- thorough peer review by experienced researchers in your field

- rapid publication on acceptance

- support for research data, including large and complex data types

- gold Open Access which fosters wider collaboration and increased citations

- maximum visibility for your research: over $100 \mathrm{M}$ website views per year

At $\mathrm{BMC}$, research is always in progress.

Learn more biomedcentral.com/submissions 